\title{
EXPERIMENTAL EVALUATION OF STRENGTH OF HONEYCOMB STRUCTURE PRODUCTS WITH POLYMER COMPOSITE SHELL
}

\author{
Aleksandrs Urbahs ${ }^{1}$, Igors Lebedevs ${ }^{2}$, Aleksandrs Sorokins ${ }^{2}$, Vladislavs Turko ${ }^{2}$ \\ ${ }^{1}$ Riga Technical University, Latvia; ${ }^{2}$ SIA “Aviatest LTD”, Latvia \\ aleksandrs.urbahs@rtu.lv, igors.lebedevs@aviatest.lv, aleksandrs.sorokins@aviatest.lv, \\ vladislav.turko@gmail.com
}

\begin{abstract}
The development of engineering technologies involving the application of composite materials is related to the necessity of reducing the weight of structures without detriment to the required strength. The article presents the results of experimental studies on the evaluation of the strength of honeycomb structure products with a polymer composite shell. The honeycomb structure of a product is made with the Nomex core of high-temperature aramid paper formed into a honeycomb structure and covered with phenolic resin. Shell material HexPly® 8552 is solid amine toughened with epoxy resin. It contains unidirectional braided carbon or glass fibre. The product was exposed to static and dynamic loading with the help of a servohydraulic testing machine.
\end{abstract}

Keywords: composite material products, Nomex core, HexPly® 8552 polymer composite shell, static and fatigue tests.

\section{Introduction}

Composite materials (CM), which have a number of advantages over metals in terms of specific strength and rigidity, are now widely used for creating structural elements intended for various purposes. The efficiency of using CM in structural elements lies in the reduction of the structure weight without detriment to the required strength, condition-based operation, etc.

However, CM have a multi-component structure, spread in thermophysical, strength and physicochemical properties (anisotropy), which leads to various types of damage (thermocyclic, fatigue, etc.) during the operation of structures and constructions.

Existing standard methods and means of control, diagnostics and testing are completely adapted to traditional structural materials (metals) [1-3].

Experimental methods used to study the mechanics of composites, such as the method of photo elasticity, strain method, moire and holography [4;5], do not solve problems associated with destruction on the micro level. Therefore, it is clear that we need further experimental research giving the opportunity to reveal the actual mechanisms of deformation and destruction and take them into account in theoretical models aimed at determining the strength of composites.

This article presents the results of experimental research on the evaluation of the static and fatigue strength of honeycomb structure products with a polymer composite shell.

\section{Materials and methods}

Honeycomb panels sized $250 \times 100 \times 45 \mathrm{~mm}$ were used as structural specimens to be tested. At the top of the specimens four holes with a diameter of $8 \mathrm{~mm}$ were drilled. The drilled holes were intended for bolts of the same diameter, through which static and/or alternating load was to be applied (Fig. 1).

The honeycomb panel contains the Nomex honeycomb core made of $385 \mathrm{~mm}$ high aramid paper. Nomex ${ }^{\circledR}$ paper is produced from different forms of aramid polymer. The applied non-metallic honeycombs are made of high-temperature aramid paper formed into a honeycomb structure and covered with phenolic resin. The combination of aramid paper and phenolic resin ensures increased strength, viscosity and chemical resistance. A honeycomb cell has a hexagonal shape.

The advantages of the applied material are:

- increased resistance to corrosion caused by chemicals;

- high mechanical strength at low densities;

- fire resistance;

- self-quenching effect;

- high resistance to impact damages and humidity; 
- low level of smoke and toxic gas emission;

- high resistance to mould outbreak;

- good dielectric properties;

- conductivity of radio and radar waves;

- low thermal conductivity.

a)

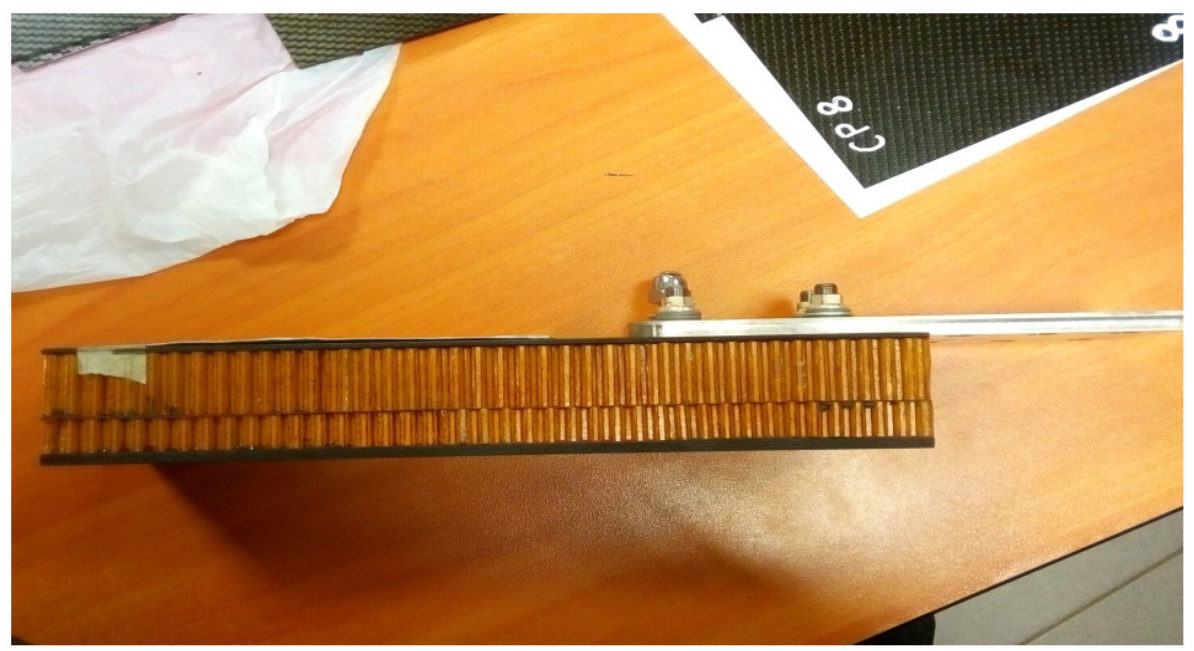

b)
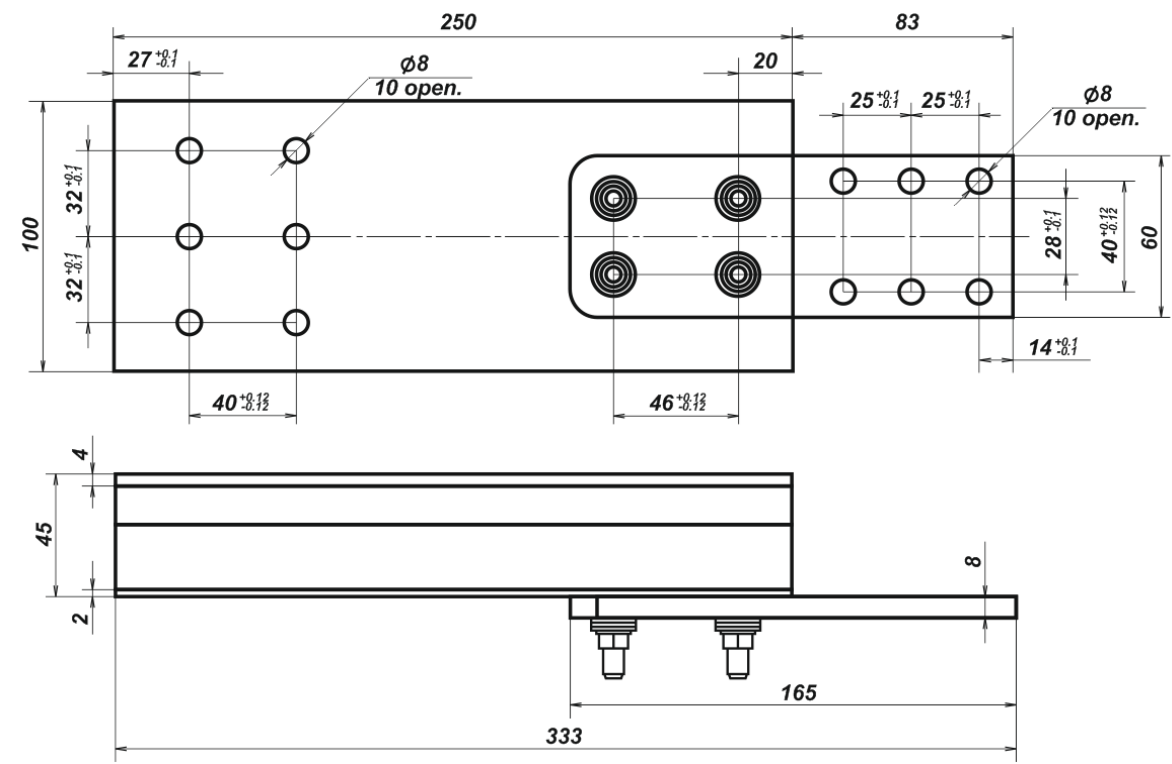

Fig.1. Appearance of test specimen: $a$ - side view photo; $b$ - plane and side view (draft)

The honeycomb core is placed between two panels made of polymer composite material HEXPLY 8552S / $37 \%$ / AGP280/C, which is 2.62-2.65 mm thick at the bottom of the specimen and 4.44-4.5 mm thick at the top of the specimen. HexPly® 8552 is a high-strength epoxy matrix consisting of cured amine toughened with epoxy resin and containing unidirectional braided carbon or glass fibre. The material was developed to be used as a part of engineering structures under temperatures of up to $+121^{\circ} \mathrm{C}\left(250^{\circ} \mathrm{F}\right)$.

The advantages of the applied material are:

- increased impact strength and resistance to damage for a wide spectrum of damages;

- relatively small weight.

The appearance of specimens to be tested for static (compression and tension) and fatigue strength is presented in Fig. 2.

ASTM D5961/d5961M-13 [6] was taken as a reference document regulating the tests. It should be pointed out that the tested specimens are structurally similar rather than standardized, they simulate elements of structures. 
The loss of specimen load-carrying capacity, i.e. ability to take up the applied load at intensive displacements of the testing machine grips, was taken as a failure criterion. The patterns of specimen failure under static tension are shown in Fig.2

a)

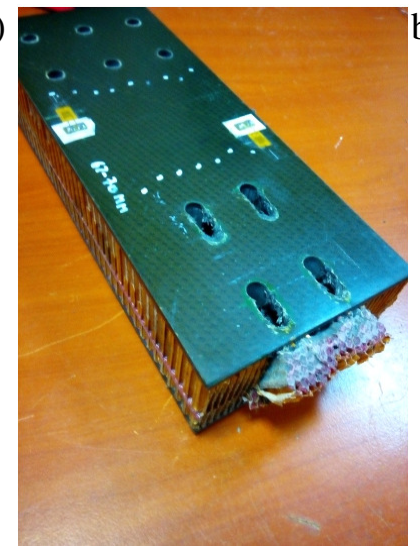

b)

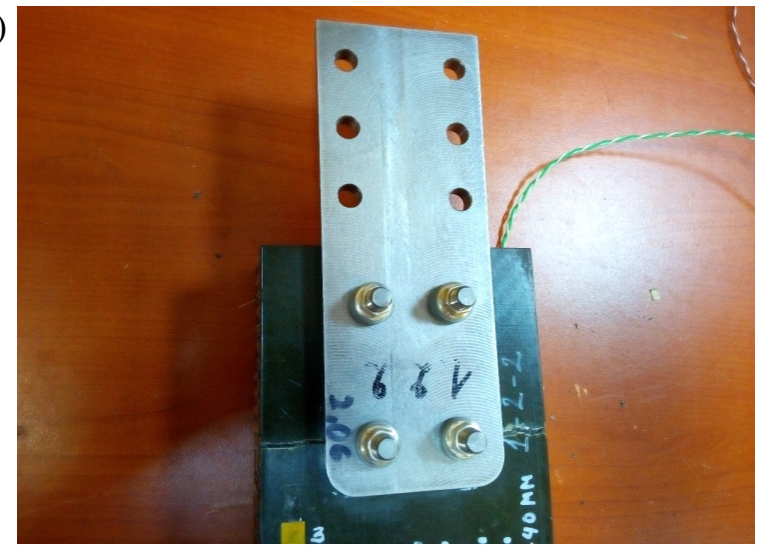

Fig.2. Specimen fracture under static tension: $\mathrm{a}$ - fracture of bolt fitting in the outer row; $\mathrm{b}-$ fracture of bolt fitting in the inner row

All the tests were carried out by using the Instron 8801 servohydraulic testing machine (Fig. 3) intended for applying static and alternating loads.

The characteristics of the Instron 8801 testing machine:

- $\quad$ Possibility of carrying out fatigue tests with different cycle forms and frequencies of up to $30 \mathrm{~Hz}$;

- $\quad$ Axial load capacity of up to $\pm 100 \mathrm{kN}(22,500$ pound-force);

- $\quad$ Loading rate from $0.1 \mathrm{~mm} \cdot \mathrm{min}^{-1}$ to $240 \mathrm{~mm} \cdot \mathrm{s}^{-1}$.

The general view of a specimen placed on the testing machine is shown in Fig. 4.

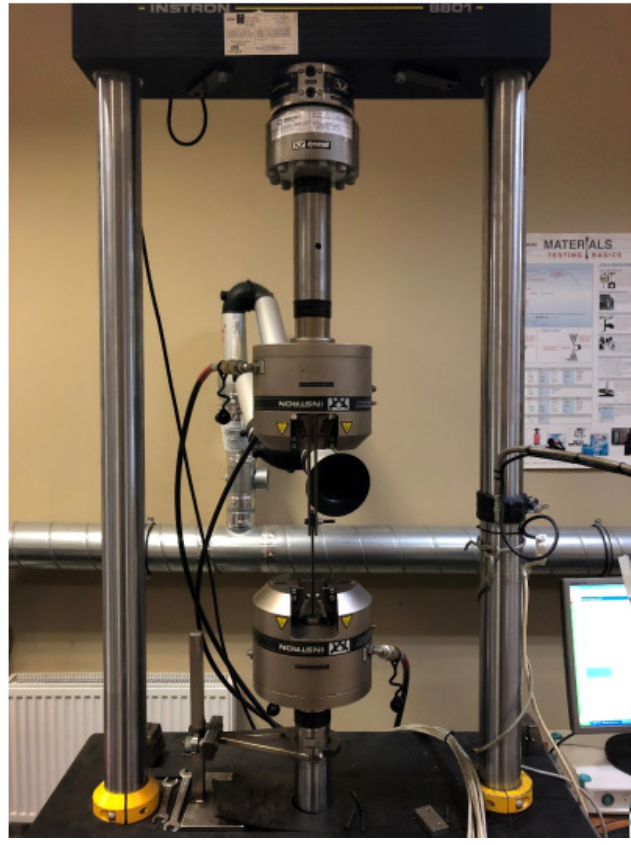

Fig. 3. Appearance of Instron 8801 floorstanding servohydraulic testing machine

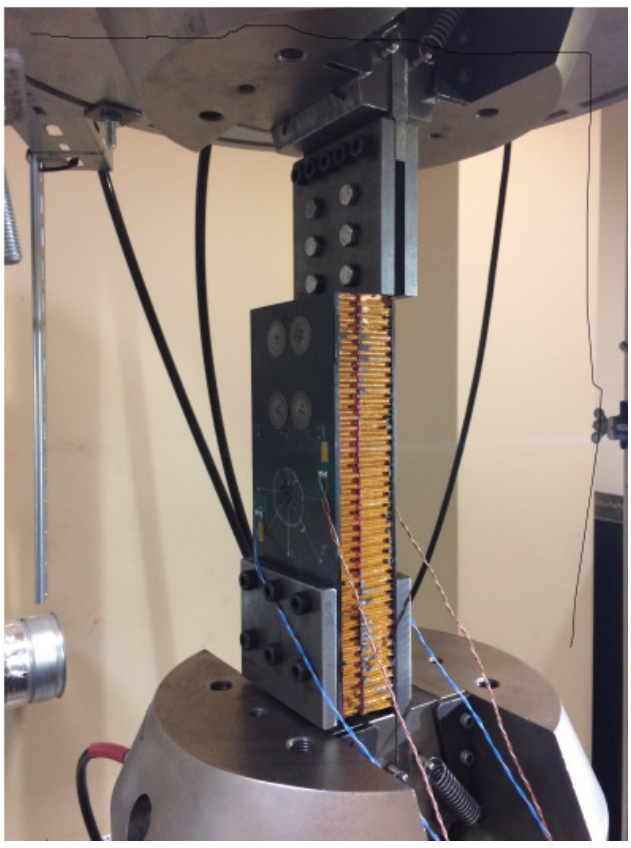

Fig. 4. Installation of structurally similar specimen on testing machine

\section{Results and discussion}

The static tests made it possible to determine the values of breaking load transferred through the bolt joints to the specimen under tension (Table 1) and compression (Table 2). 
It should be noted that the loss of the specimen load-carrying capacity occurred both in case of substantial displacement of fastening bolts (Fig. 2 a) and in case of panel body failure (Fig. 2 б). Another curious fact is that failure under tension can be observed not only along the outer row of bolts, which is typical of homogeneous structures, but also along the inner row. This leads to a big spread of static strength properties and makes it difficult to forecast their limiting values due to the fact that failures are not uniform. The reasons for the failure mechanism change obviously lie in the peculiarities of composite material formation.

Table 1

Static tension test results

\begin{tabular}{|c|c|c|c|c|c|}
\hline \multirow{2}{*}{ Specimen } & \multicolumn{5}{|c|}{ Specimen geometry } \\
\cline { 2 - 6 } & $\begin{array}{c}\text { Skin thickness } \\
1, \mathrm{~mm}\end{array}$ & $\begin{array}{c}\text { Skin thickness } \\
2, \mathrm{~mm}\end{array}$ & Width, mm & $\begin{array}{c}\text { Hole diameter, } \\
\mathrm{mm}\end{array}$ & $\begin{array}{c}\text { Failure } \\
\text { Load, N }\end{array}$ \\
\hline $1-2-2$ & 2.62 & 4.44 & 100.10 & 7.84 & 84552 \\
\hline $1-2-3$ & 2.62 & 4.45 & 100.29 & 7.84 & 82992 \\
\hline $\begin{array}{c}\text { Mean } \\
\text { Value }\end{array}$ & 2.62 & 4.45 & 100.20 & 7.84 & 83722 \\
\hline
\end{tabular}

Loads for cyclic loading were selected based on the data obtained through static tests. The testing frequency was identified separately for each level of loading, so that the loading amplitude could fully embrace the set levels of loading. Cyclic loading was carried out as a symmetric cycle with a frequency of 0.1 to $0.3 \mathrm{~Hz}$. Due to small frequency of loading it was assumed that durability does not depend on the frequency of loading.

Table 2

Static compression test results

\begin{tabular}{|c|c|c|c|c|c|}
\hline \multirow{2}{*}{ Specimen } & \multicolumn{5}{|c|}{ Specimen geometry } \\
\cline { 2 - 6 } & $\begin{array}{c}\text { Skin thickness } \\
1, \mathrm{~mm}\end{array}$ & $\begin{array}{c}\text { Skin thickness } \\
2, \mathrm{~mm}\end{array}$ & Width, mm & $\begin{array}{c}\text { Hole diameter, } \\
\mathrm{mm}\end{array}$ & $\begin{array}{c}\text { Failure } \\
\text { Load, N }\end{array}$ \\
\hline $1-2-4$ & 2.65 & 4.50 & 100.00 & 7.84 & $\begin{array}{c}\text { minus } \\
107021\end{array}$ \\
\hline $2-2-1$ & 2.65 & 4.50 & 100.00 & 7.84 & $\begin{array}{c}\text { minus } \\
149098\end{array}$ \\
\hline $\begin{array}{c}\text { Mean } \\
\text { Value }\end{array}$ & 2.65 & 4.50 & 100.00 & 7.84 & $\begin{array}{c}\text { minus } \\
128060\end{array}$ \\
\hline
\end{tabular}

The thickness of skin panel No. 1 was $2.65 \mathrm{~mm}$; the thickness of skin panel No. 2 was $4.50 \mathrm{~mm}$. The specimen width was $300 \mathrm{~mm}$, while the specimen length was $450 \mathrm{~mm}$. Thus, the alternating load was taken up mostly by the layers of the skin panels with an area of $2145 \mathrm{~mm}^{2}$.

During the fatigue loading, reaching the ultimate increase of the bolt hole diameter by $50 \%$ of the reference value, i.e. by $4 \mathrm{~mm}$, was taken as a failure criterion. This criterion is defined in [6]. Examples of hole elongation after the cessation of fatigue tests are presented in Fig. 5.

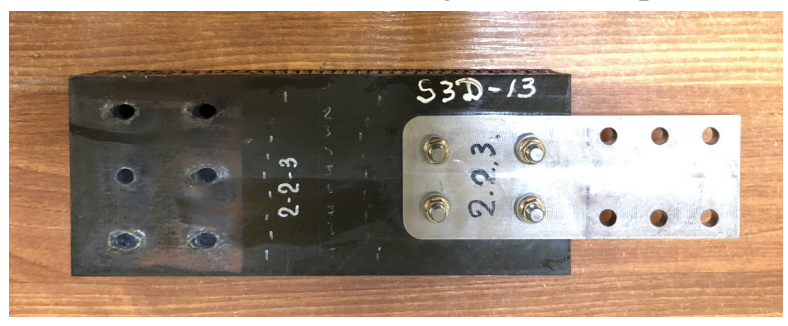

Fig. 5. Service hole elongation after the end of fatigue test

According to the results of testing 15 specimens (see Tables 3 and 4), paying no regard to the effect of loading frequency upon fatigue life, there was plotted a fatigue curve in double logarithmic coordinates Lg P - Lg N (Fig. 6), where P is the amplitude of loading applied to the specimen, and $\mathrm{N}$ is the number of load cycles up to the end of the fatigue tests. The fatigue curve was plotted for the 
average values of $\mathrm{Lg}$, load $\mathrm{P}$ and durability $\mathrm{N}$. The data for 4 specimens are selectively presented in Table 3.

Analysing the changes in fatigue parameters, it should be noted that the variation coefficient increases depending on the increase of the load (Fig. 6), which in essence differs from the behaviour of homogeneous structures, where dispersion and the variation coefficient decrease as the load increases [7]. This peculiarity leads to difficulties with determining the allowable operating time in terms of working loads for structures made of composite materials [8]. In any case, the wide diversity of composite materials and composite structures requires a substantial volume of fatigue testing for separate structures and/or their elements.

Table 3

Fatigue test data

\begin{tabular}{|c|c|c|c|}
\hline Specimen & Cycle load amplitude, $\mathbf{N}$ & Load frequency, $\mathbf{~ H z}$ & Life time, cycles \\
\hline S3-1 & 26117 & 0.3 & 15382 \\
\hline S3-3 & 29487 & 0.2 & 1709 \\
\hline S3-4 & 23168 & 0.5 & 143110 \\
\hline S3-5 & 26117 & 0.3 & 43935 \\
\hline S3-6 & 26117 & 0.3 & 31970 \\
\hline S3-7 & 26117 & 0.3 & 12002 \\
\hline S3-8 & 29487 & 0.2 & 791 \\
\hline S3-9 & 29487 & 0.2 & 2553 \\
\hline S3-10 & 29487 & 0.2 & 1424 \\
\hline S3-11 & 29487 & 0.2 & 4308 \\
\hline S3-12 & 29487 & 0.2 & 844 \\
\hline S3-13 & 23168 & 0.5 & 55664 \\
\hline S3-14 & 26117 & 0.3 & 10759 \\
\hline S3-15 & 26117 & 0.5 & 86913 \\
\hline S3-19 & 23168 & 0.5 & 34720 \\
\hline
\end{tabular}

S-N curve data

Table 4

\begin{tabular}{|c|c|c|c|}
\hline $\begin{array}{c}\text { Amplitude of } \\
\text { load, Lg P }\end{array}$ & $\begin{array}{c}\text { Average work } \\
\text { time, M(Lg N) }\end{array}$ & $\begin{array}{c}\text { Mean root-square } \\
\text { deviation, S(Lg N) }\end{array}$ & $\begin{array}{c}\text { Variation factor, } \\
\text { V(Lg N), \% }\end{array}$ \\
\hline 4.36 & 4.81 & 0.31 & 6.5 \\
\hline 4.42 & 4.40 & 0.36 & 8.2 \\
\hline 4.50 & 3.21 & 0.28 & 8.8 \\
\hline
\end{tabular}

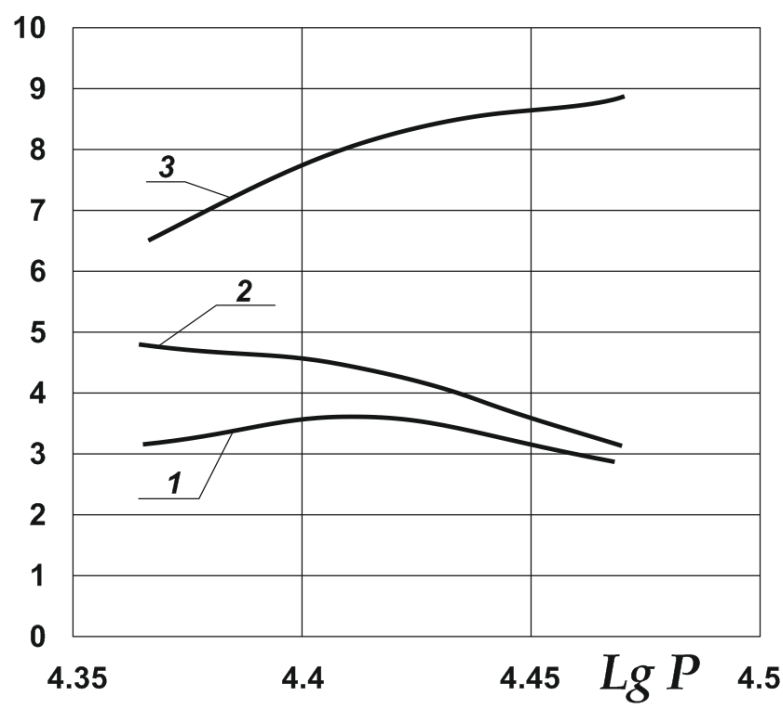

Fig. 6. S-N curve for structurally similar composite specimens 


\section{Conclusions}

1. Static (tension and compression) and fatigue testing of structurally similar specimens made of composite materials has been carried out by using the INSTRON 8801 servohydraulic testing machine.

2. Honeycomb panels sized 250 x 100 x $45 \mathrm{~mm}$ were used as specimens. Nomex honeycomb core was placed between two panels made of polymer composite material HEXPLY 8552S / $37 \%$ / AGP280/C.

3. As a result of static tests, it has been revealed that under compression the absolute values of breaking load are 1.5 times higher than the values of breaking load under tension.

4. During the fatigue tests, the selected amplitude of the alternating load of symmetric cycle was approximately two times smaller than the limit load under tension. The frequency of loading was $0.1 \ldots 0.3 \mathrm{~Hz}$. Elongation of the service holes by more than half diameter was taken as the failure criterion.

5. The change of the fatigue characteristics - the average logarithm of operating cycles, its root mean square deviation and the variation coefficient depending on the logarithm of load intensity - are to some extent different from the results of testing structural specimens made of composite materials. This fact leads to a conclusion about greater inhomogeneity of strength indices, which requires increasing the volume of testing when optimizing the structure of honeycomb blocks with the aim to increase the life of real structures made of honeycomb blocks.

\section{Acknowledgements}

This work has been supported by the European Regional Development Fund within the project No 1.1.1.1/16/A/073 "High Performance Erosion Resistant Multifunctional coatings for Aircraft Composite Structures (PEROMACS)"

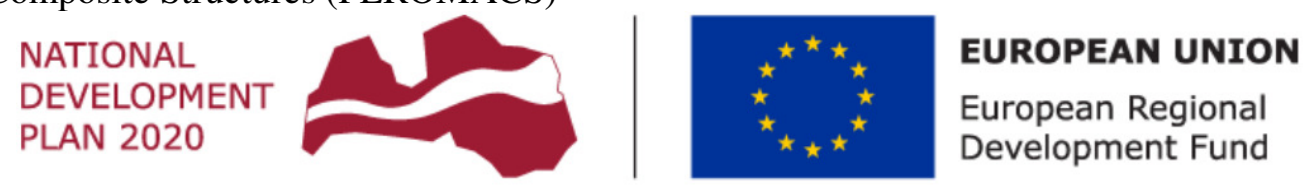

$$
\text { I N VESTING IN YOUR FUTURE }
$$

\section{References}

[1] Kelly A. and Davies G.J. The Principles of the Fibre Reinforcement of Metal, Rev. Vol.10, No. 37, 1965, p. 1.

[2] Pollock A.A. Acoustic Emission Inspection, Metals Handbook, 9th edition, Materials Park, Ohio, ASM International, Vol. 17, 1989, pp. 278-294.

[3] Urbach A., Banov M., Turko V. Hypothesis of local zones with dependent fatigue damages accumulation. Applied Mechanics and Materials, Vol. 232, Trans Tech Publications, Switzerland, 2012, pp. 19-23. DOI: 10.4028/www.scientific.net/AMM.232.19

[4] Urbahs A., Banovs M., Harbuz Y., Turko V., Khodos N., Feščuks J. Estimation of Mechanical Properties of the Anisotropic Reinforced Plastics with Aplication of the Method of Acoustic Emission. Transport and Telecommunication, Vol. 2, 2010, pp. 68-75.

[5] Urbahs A., Banovs M., Carjova K., Turko V., Feshchuk J. Research of the micromechanics of composite materials with polymer matrix failure under static loading using the acoustic emission method. Aviation, Vol.21 (1), 2017, pp. 9-16. DOI: 10.3846/16487788.2016.1264720

[6] ASTM Standard. D5961/D5961M-13 Standard Test Method for Bearing Response of Polymer Matrix Composite Laminates.

[7] Кордонский Х.Б., Фридман Я.Ф. Некоторые вопросы вероятностного описания усталостной долговечности (Some questions of the probabilistic description of fatigue durability) //Заводская лаборатория. т.42, №7, 1976 , с 829-847. (In Russian).

[8] Turko V. Principle of local zones applied to fatigue prone large-scale Designs. Lambert Academic Publishing. 2015, 149 p. 